\title{
PENGEMBANGAN MEDIA CAI (COMPUTER ASSISTED INSTRUCTION) PADA MATA PELAJARAN BAHASA INGGRIS UNTUK KELAS X DI SEKOLAH MENENGAH KEJURUAN
}

\author{
Rifa Usaifa ${ }^{1}$, Mochammad Sukardjo ${ }^{2}$, \& Murni Winarsih ${ }^{3}$ \\ email: rifaussaifa5@gmail.com ${ }^{1}$, msoekardjo@unj.ac.id ${ }^{2}$, \\ murniwinarsih127@gmail.com ${ }^{3}$, \\ Program Studi Teknologi Pendidikan, Universitas Negeri Jakarta \\ Jalan Rawamangun Muka Raya, RT.11/RW.14, Rawamangun, Kec. Pulo Gadung, Kota Jakarta \\ Timur, Daerah Khusus Ibukota Jakarta 13220
}

\begin{abstract}
Abstrak: Tujuan dari penelitian ini adalah mengembangkan media pembelajaran interaktif yang dirancang berdasarkan karakteristik pembelajaran dengan bantuan komputer atau CAI (Computer Assisted Instruction) untuk meningkatkan hasil belajar bahasa Inggris di SMK. Media pembelajaran ini dikembangkan untuk membantu siswa Sekolah Menengah Kejuruan yang belum mencapai standar kompetensi yang ditetapkan pada mata pelajaran Bahasa Inggris. Metode penelitian yang digunakan adalah metode penelitian dan pengembangan. Model pengmbangan yang digunakan untuk mengembangkan media CAI ini adalah model Hannafin and Peck. Data dikumpulkan menggunakan angket, wawancara, dokumen hasil pembelajaran dan tes. Hasil uji validasi pakar materi, media, desain instruktional, uji satu-satu, uji kelompok kecil serta hasil uji lapangan dengan menggunakan perhitungan t-test menunjukkan terdapat perbedaan yang signifikan terhadap hasil belajar siswa sebelum dan sesudah menggunakan media CAI. Dengan kata lain media CAI untuk pembelajaran Bahasa Inggris dinilai efektif dan dapat meningkatkan hasil belajar siswa.
\end{abstract}

Kata-kata Kunci: Bahasa Inggris, media pembelajaran interaktif, pengembangan

\section{DEVELOPMENT OF CAI (COMPUTER ASSISTED INSTRUCTION) MEDIA IN ENGLISH SUBJECT FOR CLASS X IN VOCATIONAL HIGH SCHOOL}

\begin{abstract}
The purpose of the study is to develop an interactive learning media that are designed based on the characteristics of learning with the help of computer or CAI (Computer Assisted Instruction) to improve English learning outcomes in vocational high school. This learning media was developed to help Vocational High School students who have not yet reached the competency standards set in English subjects. The research method used is a research and development method. The development model used to develop CAI media is the model from Hannafin and Peck. Data were collected using questionnaires, interviews, learning outcomes documents and tests. Validation test results for material, media and design experts instructional, one-on-one test, small group test and the results of field tests using t-test calculations showed that there were significant differences in student learning outcomes before and after using CAI media. In other words, CAI media for learning English was considered effective and can help improving students' learning outcomes.
\end{abstract}

Keywords: development, English, interactive learning media 


\section{PENDAHULUAN}

Berbagai hasil penelitian sebelumnya menunjukkan bahwa pengembangan media pembelajaran berbantuan komputer (computer assisted instruction/CAI) mendapatkan respon yang baik dan mampu meningkatkan hasil belajar siswa. Penelitian yang dilakukan oleh Komang dkk (2017) dengan judul Pengembangan E-Modul Berbantuan CAI Pada Mata Pelajaran Fotografi Kelas X Desain Komunikasi Visual DiSMK Negeri 1 Sukasada. Peneliti menjelaskan bagaimana cara mengembangkan e-modul berbantuan media CAI pada mata pelajaran fotografi. Hasil dari penelitian tersebut bahwa siswa terlihat antusias dan lebih aktif selama proses pembelajaran berlangsung serta respon dari siswa dan guru terhadap pengembangan e-modul berbantuan media CAI sangat positif. Sementara, Samsudin (2017) meneliti tentang pengembangan aplikasi computer assisted instruction (CAI) dalam pembelajaran matematika bangun ruang. Peneliti menjelaskan dengan sangat terperinci materi tentang bangun ruang (geometri) pada mata ajar matematika. Hasil dari penelitian ini menunjukkan bahwa dengan sistem serta media pembelajaran CAI dapat meningkatkan keinginan siswa untuk mempelajari mata ajar matematika yang dimana mata ajar ini cukup sulit untuk mereka pahami.

Penelitian tentang pengembangan media CAI (Computer Assissted Instruction) juga dilakukan oleh Candraningrum \& Sumarno (2020) pada materi sistem pencernaan manusia pada mata pelajaran biologi kelas VIII di Gresik, Jawa Timur. Peneliti menjelaskan bahwa pengembangan media CAI pada mata pelajaran sistem pencernaan manusia menjadikan fasilitas komputer di sekolah termanfaatkan dan menambah minat belajar peserta didik dalam proses pembelajaran materi sistem pencernaan manusia. Sementara, Yulianti \& Kristanto (2018) melakukan penelitian pengembangan media computer assisted instruction pada mata pelajaran dasar desain grafis untuk kelas X Jurusan Multimedia di SMK Muhammadiyah 2 Surabaya. Peneliti menyimpulkan bahwa pengembangan media CAI (Computer Assisted Instruction) ini menggunakan model ADDIE dengan 5 tahapan, yaitu Analysis, Design, Development, Implementation, dan Evaluate. Setelah melalui seluruh tahap pada model ADDIE ini, maka media CAI (Computer Assisted Instruction) dinyatakan layak dan efektif digunakan dalam kegiatan pembelajaran mata pelajaran dasar desain grafis di SMK Muhammadiyah 2 Surabaya.
Selanjutnya penelitian yang dilakukan oleh Fadhillah \& Mariono (2020) dkk, dengan judul penelitian tentang Pengembangan Media Pembelajaran CAI Untuk Meningkatkan Hasil Belajar Pada Mata Pelajaran Kimia Materi Pokok Struktur Atom Kelas $X$ Di SMA Cendekia Sidoarjo, Jawa Timur, yang menyatakan bahwa pengembangan media CAI yang dilakukan ditujukan secara khusus bagi kegiatan pembelajaran bagi peserta didik kelas X SMA Cendekia Sidoarjo, Jawa Timur saja. Andai media CAI tersebut akan digunakan oleh sekolah lain, diperlukan analisis kebutuhan lagi untuk mengetahui apakah media sesuai dengan karateristik peserta didik, sarana dan prasarana serta penerapan kurikulum di setiap sekolah.

Adapun perbedaan penelitian yang dilakukan dengan penelitian sebelumnya adalah sebagai berikut: pertama produk CAI yang dikembangkan oleh Komang dkk adalah pengembangan produk untuk mata pelajaran fotografi sedangkan penelitian yang dilakukan oleh Samsudin adalah pengembangan produk CAI untuk mata pelajaran matematika dan juga penelitian yang dilakukan oleh Cahyaningrum, Yulianti dan Fadhilah pun menggunakan mata pelajaran yang berbeda. Pada penelitian ini, peneliti akan mengembangkan produk untuk mata pelajaran Bahasa Inggris dengan menggunakan media CAI sebagai media dalam proses pembelajaran.

Penemuan-penemuan baru dalam bidang ilmu dan teknologi telah memberikan pengaruh dan kemajuan yang besar dalam bidang pendidikan. Penemuan-penemuan tersebut memunculkan berbagai macam pembaharuan dalam bidang pendidikan di antaranya adalah munculnya berbagai macam jenis media pembelajaran salah satunya adalah media CAI (Computer Assisted Instruction) (Hamalik, 1986).

CAI merupakan pengembangan teknologi informasi terpadu terdiri dari komunikasi (interaktif), audio, video, penampilan citra (image) yang disebut juga sebagai teknologi multimedia. Media ini mencakup penggunaan komputer yang berhubungan secara langsung degan siswa maupun pendidik (Purwani, 2013).

Penelitian yang berorientasi produk ini dikembangkan untuk siswa di Sekolah Menengah Kejururan/SMK. Mengingat orientasi dari Sekolah Menengah Kejururan adalah dunia kerja, maka diperlukan hal mendasar yang selalu menjadi prasyarat sebelum masuk ke dunia kerja yaitu menguasi Bahasa Inggris. 
Hasil observasi dan wawancara terhadap guru Bahasa Inggris di SMK Daarussalaam memberikan informasi mengenai metode pembelajaran, hasil belajar siswa, dan opini siswa mengenai mata pelajaran Bahasa Inggris. Metode pembelajaran yang digunakan di SMK Darussalaam Kabupaten Sukabumi, Jawa Barat, didominasi oleh metode ceramah. Metode ceramah dan minimnya bahan ajar, mengakibatkan siswa merasa pelajaran Bahasa Inggris adalah pelajaran yang sulit dan membosankan, sehingga siswa pasif saat pembelajaran berlangsung dan hasil pembelajaran siswa menjadi tidak memuaskan. Dokumen yang diperoleh menunjukkan bahwa 50\% siswa hasil belajarnya kurang dari Kriteria Ketuntasan Maksimal/KKM. Ada 20 siswa dari total 40 siswa memiliki nilai KKM di bawah 75 yang ditetapkan oleh pihak sekolah sebagai nilai KKM untuk mata pelajaran bahasa Inggris.

Untuk mengatasi masalah ini, maka diperlukan media pembelajaran yang dapat merangsang siswa agar lebih aktif dalam proses pembelajaran mata pelajaran Bahasa Inggris, karena sebuah media dapat dikatakan sebagai media pembelajaran jika pesan yang dibawa berisi informasi-informasi yang dapat mendukung siswa mencapai tujuan pembelajaran (Pribadi, 2017).

Fokus dalam penelitian adalah untuk mengembangkan sebuah produk pada mata pelajaran Bahasa Inggris dengan menggunakan CAI sebagai media pembelajaran yang akan digunakan. Materi yang akan dikembangkan adalah pada mata pelajaran Bahasa Inggris kelas $\mathrm{X}$ semester ganjil tentang describing people, places and things, dengan menggunakan tiga pokok bahasan yaitu social functions yang bertujuan agar siswa dapat memahami fungsi sosial pada teks deskriptif sederhana. Learning focus bertujuan agar siswa dapat mengingat struktur teks deskriptif sederhana. Grammar bertujan agar siswa dapat menganalisis unsur kebahasaan pada teks deskriptif sederhana

Penelitian ini bertujuan dua hal, yaitu: (1) menghasilkan produk berupa sebuah media pembelajaran Bahasa Inggris berbantuan komputer yang dikemas dalam bentuk compact disc/CD, yang digunakan agar dapat membantu siswa dalam upaya memahami materi yang disajikan oleh guru. Sementara tujuan (2) menguji efektivitas media CAI yang telah dikembangkan untu digunakan pada pembelajaran Bahasa Inggris.

Jadi, penelitian ini akan menjawab dua pertanyaan penelitian, yaitu: (1) bagaimana mengembangkan produk media CAI (Computer
Assisted Instruction) pada materi describing people, places and things? (2) apakah media pembelajaran CAI (Computer Assisted Instruction) efektif digunakan untuk pembelajaran Bahasa Inggris pada materi describing people, places and things?

Model pengembangan yang dirujuk dalam pengembangan media CAI oleh banyak penelitian adalah model Hannafin and Peck (1988). Model ini dipilih sebagai model pengembangan media, karena memiliki beberapa kelebihan di antaranya adalah (1) berorientasi pada produk, (2) penilaian dan revisi dilakukan dalam setiap fase, (3) menekankan proses penilaian dan evaluasi yang mengikutsertakan proses yaitu meliputi: proses pengujian dan penilaian media pembelajaran yang melibatkan ketiga fase secara berkesinambungan. Berikut model Hannafin \& Peck:

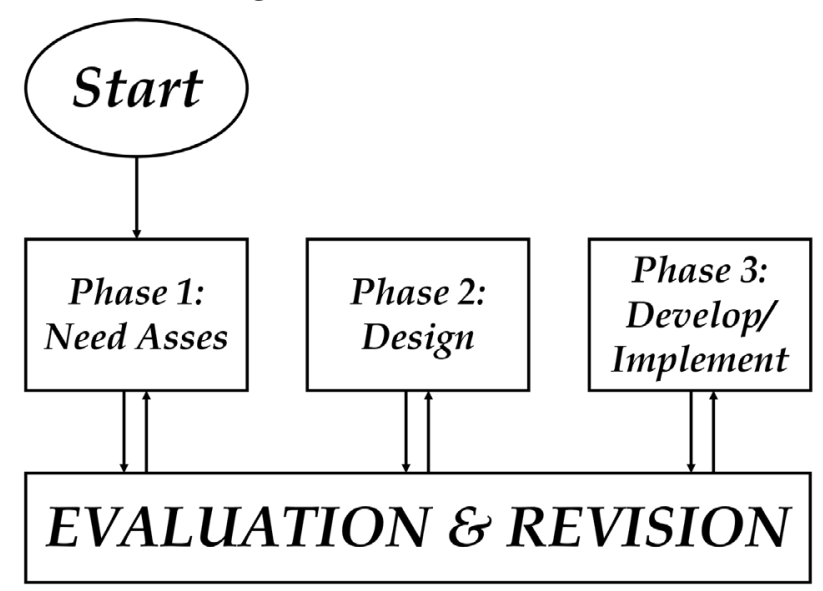

Gambar 1. Model Hannafin \& Peck (1988)

\section{METODE PENELITIAN}

Seperti telah dituliskan sebelumnya bahwa penelitian pengembangan ini menggunakan model Hannafin \& Peck (1988). Penelitian ini dilaksanakan di SMK Daarussalaam Sukabumi Jawa Barat. Pengkajian media dilakukan pada ahli media dan ahli materi. Sedangkan ujicoba dilakukan pada siswa/siswi kelas $X$ di sekolah tersebut. Waktu penelitian dimulai dari Februari 2020 sampai dengan April 2020.

Metode penelitian yang digunakan dalam penelitian ini adalah metode penelitian pengembangan. Metode ini digunakan untuk mengembangkan dan memvalidasi suatu produk Pendidikan, terutama CAI. Selanjutnya dilakukan uji coba untuk melihat keabsahan produk tersebut. Tahapan uji coba ini dilakukan untuk mendapatkan data dan informasi yang berfungsi untuk memperbaiki produk agar didapatkan hasil produk yang berkualitas untuk kegiatan pembelajaran siswa. Adapun langkahlangkah yang dilakukan dalam pengembangan model dalam penelitian ini adalah sebagai berikut: 


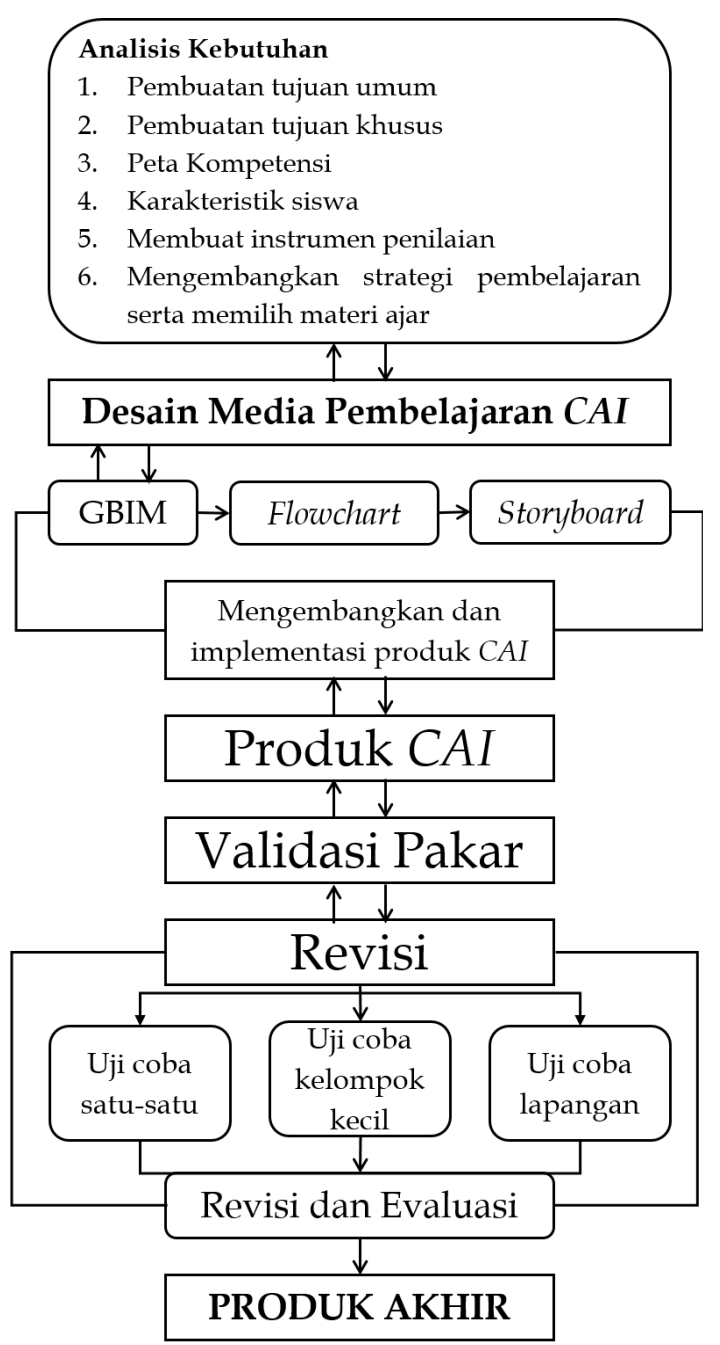

Gambar 2. Langkah Pengembangan Media CAI Yang Direncanakan

Pada analisis kebutuhan, dilakukan penelitian pendahuluan yang berguna untuk memperoleh informasi awal tentang kebutuhan, kondisi lapangan, dan studi kelayakan. Pengumpulan data dilakukan dengan melakukan observasi dan wawancara. Observasi pada proses pembelajaran di kelas bertujuan untuk memperoleh deskripsi kegiatan guru saat menerapkan pendekatan atau metode dalam pembelajaran, bahan ajar, media yang dipakai, evaluasi dan perilaku siswa dalam mengikuti pembelajaran. Sementara wawancara dilakukan pada guru mata pelajaran bahasa Inggris dan wawancara pada 5 orang siswa mengenai materi pelajaran yang dianggap paling sulit.

Tabel 1.

Pedoman Wawancara Guru

\begin{tabular}{cl}
\hline No & \multicolumn{1}{c}{ Pertanyaan } \\
\hline 1 & $\begin{array}{l}\text { Berapa lama mengajar diSMK Daarussalaam? Berapa lama } \\
\text { mengajar di kelas X? }\end{array}$ \\
2 & $\begin{array}{l}\text { Berapa jumlah peserta didik yang belajar di kelas X saat } \\
\text { ini? }\end{array}$ \\
3 & $\begin{array}{l}\text { Bagaimana hasil belajar siswa kelas pada pembelajaran } \\
\text { bahasa inggris? }\end{array}$
\end{tabular}

4 Bagaimana cara guru menyampaikan materi kepada siswa?

5 Bagaimana respon siswa pada pembelajaran?

6 Media pembelajaran apakah yang diketahui?

7 Media pembelajaran apa yang sering gunakan pada saat proses pembelajaran?

8 Bagaimana respon siswa terhadap media yang dipakai pada pembelajaran bahasa inggris?

9 Apakah dalam proses pembelajaran pernah menggunakan media pembelajaran CAI?

Secara garis besar wawancara pada guru dan siswa bertujuan untuk (1) mengetahui metode pembelajaran yang dipakai selama proses pembelajaran berlangsung; (2) mengetahui media pembelajaran yang digunakan di kelas; (3) mengetahui karakteristik peserta didik, dan (4) mengetahui perolehan nilai peserta didik dengan menggunakan media yang dipakai selama proses kegiatan belajar mengajar.

Hasil analisis kebutuhan ini kemudian digunakan untuk merancang media CAI yang diperlukan pada materi belajar Bahasa Inggris kelas $X$. Analisis dilakukan dengan membuat rancangan yang didiskusikan dengan ahli materi, yaitu guruguru yang mengajar mata pelajaran Bahasa Inggris di sekolah tersebut. Hasil rancangan berupa naskah, pada akhirnya dikembangkan dengan langkahlangkah praktis berbasis media komputer. Pada proses produksi dilakukan oleh pengembang media.

Setelah media CAI selesai dikembangkan dengan proses evaluasi dan revisi, media CAI tersebut diuji formatif dengan melakukan uji satu-satu, uji kelompok kecil dan uji coba lapangan. Uji satu-satu menguji media CAI Ketika digunakan mandiri oleh siswa, sedangkan uji kelompok kecil digunakan oleh siswa secara berkelompok dan uji lapangan dilakukan untuk mengukur kelayakan produk media CAI mata pelajaran Bahasa Inggris. Guna evaluasi formatif ini adalah untuk mengumpulkan data untuk mengidentifikasi masalah dalam pembelajaran, agar pembelajaran menjadi lebih baik. Pada uji lapangan, peneliti memberikan pretest dan postest pada siswa seputar isi materi program media CAI. Untuk melihat ada tidaknya signifikasi perbedaan hasil belajar siswa sebelum dan setelah menggunakan media CAI dilakukan Uji T Statistik.

Data angket yang didapat dari para ahli, uji coba satu, kelompok kecil dam uji coba lapangan akan dianalisis dengan cara menghitung nilai berdasarkan skala penilaian berikut:
$3,26-4,00$
$=$ Sangat Baik
$2,51-3,25$
$=$ Baik
$1,76-2,25$
$=$ Cukup Baik
$1-1,75$
$=$ Kurang Baik 


\section{HASIL DAN PEMBAHASAN}

\section{Hasil Penelitian dan Pengembangan}

Sesuai dengan model pengembangan yang digunakan, yaitu Hannafin \& Peck (2011), maka langkah pertama adalh merumuskan hasil analisis kebutuhan, kemudian mendesain dan mengembangkan dan mengimplementasikan pada konteks pengguna media CAI di lokasi ujicoba. Setiap langkah selalu melalui proses evaluasi dan revisi.

\section{Hasil Fase Analisis Kebutuhan}

Analisis kebutuhan dilakukan dengan mewawancara guru dan siswa. Hasil wawancara pada guru berdasarkan 9 pertanyaan seperti disebutkan pada tabel 1, menyatakan bahwa guru mata pelajaran Bahasa Inggris telah mengajar selama 6 tahun, dan secara khusus pada kelas $\mathrm{X}$ selama 4 tahun terakhir. Jumlah siswa kelas $X$ sebanyak 62 siswa dari 2 rombongan belajar. Sedangkan hasil belajar siswa dianggap cukup memuaskan. Sedangkan dalam pembelajaran, guru menggunakan metode ceramah dan diskusi saja. Guru menggunakan buku dan komputer jika diperlukan untuk presentasi. Selain guru juga menggunakan buku sebagai pedoman mengajar di kelas. Ketika Ia mengajar, menurut guru, respon siswa kurang baik, kadang ada yang ngobrol dan mengantuk. Kadang mereka merasa bosan dan tidak bersemangat untuk mempelajari materi yang baru. Guru juga mengaku belum pernah mendengar media CAI dalam pembelajaran.

Sementara, hasil analisis kebutuhan yang dilakukan dengan melakukan wawancara pada 5 orang siswa kelas X SMK, menemukan bahwa materi describing people, places, and things adalah materi yang menurut siswa sulit dipahami karena pada materi tersebut dipelajari juga ketatabahasaan atau grammar. Dari ke-5 siswa tersebut menyatakan bahwa mereka tidak mengerti akan materi tersebut dan siswa menyatakan bahwa mereka merasa bosan dan tidak tertarik dengan materi tersebut karena guru hanya menggunakan buku saja tanpa dibantu dengan sebuah media yang akan membuat siswa termotivasi untuk mempelajari materi tersebut, dan guru pun tidak pernah menggunakan media pembelajaran yang menarik.

Berdasarkan hasil analisis kebutuhan, perlu dikembangkan intervensi belajar pada materi media pembelajaran yang dapat membantu siswa memahami ketatabahasaan (grammar). Penggunaan media cetak (buku) siswa merasa kesulitan untuk memahami materi pelajaran yang akan disampaikan, khususnya pada materi describing people, places and thing.

\section{Hasil Fase Desain}

Hasil analisis kebutuhan tersebut kemudian dilakukan proses identifikasi tujuan pembelajaran umum, merumuskan tujuan pembelajaran khusus, menyusun peta kompetensi, melakukan analisis siswa, membuat instrumen penilaian, membuat strategi pembelajaran, dan memilih materi yang akan diajarkan.

Tujuan umum dari materi describing people, places and thing adalah agar siswa dapat mengidentifikasi fungsi sosial, struktur teks, dan unsur kebahasaan pada teks deskriptif sederhana tentang orang, tempat wisata, dan bangunan bersejarah, sesuai dengan penggunaan konteks. Sedangkan tujuan khusus ada 3, yaitu: (1) apabila siswa diberikan teks deskriptif sederhana dapat memahami fungsi sosial pada teks tersebut; (2) apabila siswa diberikan teks deskriptif sederhana siswa dapat mengingat struktur teks deskrptif dengan baik, dan (3) apabila siswa diberikan teks deskriptif sederhana siswa dapat menganalisis unsur kebahasaan pada teks tersebut.

Setelah mengidentifikasi tujuan pembelajaran khusus langkah selanjutnya adalah analisis pembelajaran/peta kompetensi, yaitu proses menjabarkan perilaku umum menjadi prilaku khusus yang tersusun secara logis dan sistematis, dengan demikian akan tergambar susunan perilaku khusus dari awal sampai akhir pembelajaran.

Pada materi describing people, place and things terdapat keterkaitan antara satu dengan yang lainnya. Keterkaitan tersebut bisa dilihat pada peta kompetensi sebagai berikut:

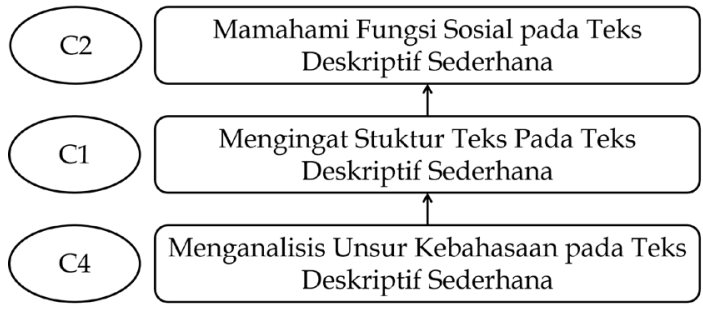

Gambar 3. Peta Kompetensi

Selanjutnya, tahap desain, peneliti melakukan tahapan pra produksi meliputi penyusunan Garis Besar Program Media (GBPM), menyusun Jabaran Materi (JM), membuat flowchart, dan membuat storyboard. Penyusunan GBPM merupakan proses pengidentifikasian program pembelajaran yang akan dituangkan dalam media CAI, setelah GBPM dibuat langkah selanjutnya adalah menyusun jabaran materi (JM). Kedua proses ini dilakukan dengan berdiskusi dengan tim guru yang mengampu mata pelajaran Bahasa Inggris di SMK Daarussalaam Kabupaten Sukabumi. 
Tabel 2.

Garis Besar Program Media (GBPM) Yang Dikembangkan

\begin{tabular}{|c|c|c|c|c|}
\hline \multirow{2}{*}{$\begin{array}{c}\text { Kompetensi } \\
\text { Dasar }\end{array}$} & \multirow{2}{*}{$\begin{array}{c}\text { Pokok } \\
\text { Bahasan }\end{array}$} & \multirow{2}{*}{$\begin{array}{c}\text { Sub Pokok } \\
\text { Bahasan }\end{array}$} & \multicolumn{2}{|c|}{ Tes Akhir } \\
\hline & & & PG & Uraian \\
\hline $\begin{array}{l}\text { Siswa dapat me- } \\
\text { mahami fungsi } \\
\text { sosial pada teks } \\
\text { deskriptif seder- } \\
\text { hana }\end{array}$ & $\begin{array}{l}\text { F ung s i } \\
\text { sosial }\end{array}$ & $\begin{array}{l}\text { Mengembang- } \\
\text { kan, mengenal } \\
\text { serta mengkri- } \\
\text { tik }\end{array}$ & 4 & \\
\hline $\begin{array}{l}\text { Siswa dapat meng- } \\
\text { ingat struktur teks } \\
\text { deskriptif seder- } \\
\text { hana }\end{array}$ & $\begin{array}{l}\text { Struktur } \\
\text { teks }\end{array}$ & $\begin{array}{l}\text { Penyebutan } \\
\text { nama dan sifat } \\
\text { orang, tem- } \\
\text { pat,banguanan } \\
\text { sertabagian-ba- } \\
\text { gian untuk } \\
\text { dideskripsikan }\end{array}$ & 5 & 5 \\
\hline $\begin{array}{l}\text { Siswa dapat } \\
\text { menganalisis } \\
\text { unsur kebaha- } \\
\text { saan pada teks } \\
\text { deskriptif }\end{array}$ & $\begin{array}{l}\text { Unsur ke- } \\
\text { bahasaan }\end{array}$ & $\begin{array}{l}\text { Kata benda, } \\
\text { kata sifat yang } \\
\text { terkait dengan } \\
\text { orang, ejaan, in- } \\
\text { tonasi bacaan } \\
\text { serta rujukan } \\
\text { kata }\end{array}$ & & 1 \\
\hline
\end{tabular}

Setelah membuat GBPM dibuatlah jabaran materi (JM) yang akan ditampilkan dalam media CAI, berikut ini merupakan penyusunannya:

Tabel 3.

Jabaran Materi/JM Yang Dikembangkan

\begin{tabular}{|c|c|c|c|c|}
\hline KB & Judul & $\begin{array}{c}\text { Tujuan } \\
\text { Pembelajaran } \\
\text { Khusus }\end{array}$ & $\begin{array}{l}\text { Uraian } \\
\text { Materi }\end{array}$ & Latihan \\
\hline 1 & $\begin{array}{l}\text { Fungsi } \\
\text { sosia } 1 \\
\text { t e k s } \\
\text { deskrip- } \\
\text { tif }\end{array}$ & $\begin{array}{l}\text { Siswa dapat } \\
\text { memahami } \\
\text { fungsi so- } \\
\text { sial pada teks } \\
\text { deskriptif se- } \\
\text { derhana }\end{array}$ & $\begin{array}{l}\text { Mengem - } \\
\text { bangkan, } \\
\text { mengenal- } \\
\text { kan serta } \\
\text { mengkritik } \\
\text { teks. }\end{array}$ & $\begin{array}{l}\text { M e n g } \\
\text { identifika- } \\
\text { si fungsi } \\
\text { sosialyang } \\
\text { terdapat } \\
\text { pada teks. }\end{array}$ \\
\hline 2 & $\begin{array}{l}\text { Struk- } \\
\text { tur teks } \\
\mathrm{p} \text { a d a } \\
\mathrm{t} \text { e k s } \\
\text { deskrip- } \\
\text { tif }\end{array}$ & $\begin{array}{l}\text { Siswa dapat } \\
\text { mengingat } \\
\text { struktur teks } \\
\text { deskriptif se- } \\
\text { derhana }\end{array}$ & $\begin{array}{l}\text { Penyebutan } \\
\text { nama dan } \\
\text { sifat orang, } \\
\text { tempat wisa- } \\
\text { ta atau temat } \\
\text { lainnya, dan } \\
\text { benguanan } \\
\text { beserta ba- } \\
\text { gian-bagi- } \\
\text { annya. }\end{array}$ & $\begin{array}{l}\text { Menyebut } \\
\text { kan struk- } \\
\text { tur teks } \\
\text { yang ada } \\
\text { pada teks } \\
\text { deskrip- } \\
\text { tif. }\end{array}$ \\
\hline 3 & $\begin{array}{l}\text { Unsur } \\
\text { k e ba - } \\
\text { hasaan } \\
\text { t e k s } \\
\text { deskrip- } \\
\text { tif }\end{array}$ & $\begin{array}{l}\text { Siswa dapat } \\
\text { menganalisis } \\
\text { unsur kebaha- } \\
\text { saan pada teks } \\
\text { deskriptif }\end{array}$ & $\begin{array}{l}\text { Kata sifat } \\
\text { dan benda } \\
\text { yang terkait } \\
\text { dengan tem- } \\
\text { pat, orang } \\
\text { dan bangu- } \\
\text { nan, ejaan, } \\
\text { ucapan atau } \\
\text { intonasi }\end{array}$ & $\begin{array}{l}\text { M e } \mathrm{n} \\
\text { analisis } \\
\text { unsur ke- } \\
\text { bahasaan } \\
\text { y a n g } \\
\text { terdapat } \\
\text { pada teks. }\end{array}$ \\
\hline
\end{tabular}

Tahap selanjutnya adalah pembuatan flowchart. Proses pembuatan flowchart merupakan tahapan yang menunjukkan alur dalam program secara logika khususnya pada tujuan pembelajaran. Proses pembuatan flowchart diawali dengan penyusunan materi yang harus disesuaikan, karena materi tersebut akan ditampilkan pada media CAI. Materi dikaji oleh ahli materi yaitu guru bahasa Inggris SMK Daarussalaam Sukabumi. Setelah itu peneliti akan melakukan perbaikan flowchart jika ada kesalahan sesuai dengan hasil kajian dari ahli materi.

Setelah pembuatan flowchart selesai, maka tahap selanjutnya adalah pembuatan storyboard. Disini peneliti akan membagi atas beberapa slide dan materi, yang setiap slidenya dibagi lagi atas audio dan visual. Di dalam bagian audio terbagi atas teks yang diaudiokan serta audio untuk backsound dan materi yang yang nantinya akan ditampilkan lewat audio. Di dalam bagian visual terdiri atas teks navigasi dan ilustrasi. Di bagian teks merupakan materi yang nantinya akan disajikan berupa teks. Di bagian navigasi merupakan tomboltombol yang tampil dalam slide serta keterangan tambahan tentang tombol tersebut. Di bagian ilustrasi merupakan cakupan tentang gambar dan motion graphics untuk membantu mejelaskan materi yang akan tampil pada setiap slide yang akan ditampilkan.

\section{Fase Pengembangan dan Implementasi}

Pada akhirnya melakukan produksi yaitu perundingan naskah, pemrograman dasar, media yang digunakan, pemrograman lanjutan, dan penyelesaian produk. Selama tahap ini, peneliti melakukan kajian pada ahli media, ahli materi, dan ahli desain pembelajaran sebagai bagian tahapan evaluasi formatif sebagaimana model pengembangan yang dipilih untuk digunakan.

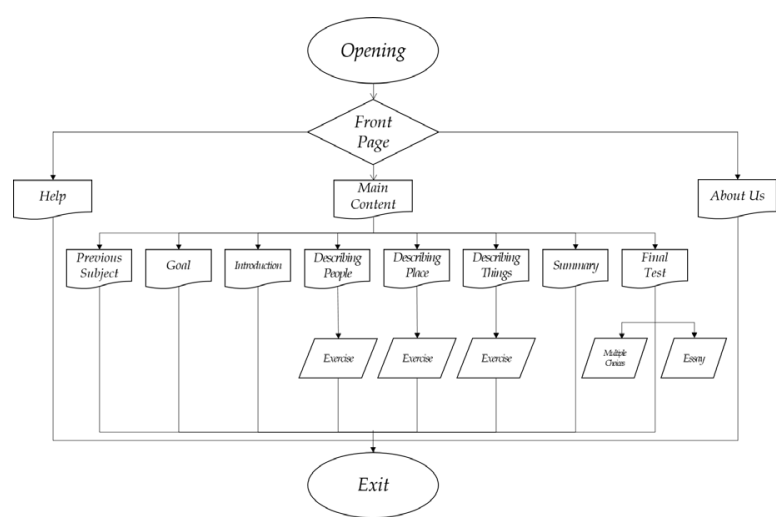

Gambar 4. Flow Chart Media CAI yang akan Dikembangkan

Untuk pengkajian ahli (expert review), oleh ahli desain pembelajaran, Dr. Robinson Situmorang, M.Pd. mulai dari GBPM dan jabaran materi sampai dengan produk ahkir. Beberapa kali revisi dilakukan, terkait beberapa masukannya. 
Berikut sejumlah masukan yang diberikan:

Tabel 4

Saran Perbaikan dalam Proses Pengembangan oleh Ahli Desain Pembelajaran

\begin{tabular}{ll}
\hline \multicolumn{1}{c}{ Saran } & \multicolumn{1}{c}{ Perbaikan } \\
\hline Memperbaiki & Untuk final test di pilihan ganda \\
test akhir & me-random nomer dengan soal \\
& yang sama jika ada peserta didik \\
& yang nilainya kurang dari 50. \\
\hline
\end{tabular}

Pengkajian oleh ahli materi dilakukan oleh Neng Syifa Oktora Masnoneh, S.S., M.Pd.

Tabel 5.

Saran Perbaikan dalam Proses Pengembangan oleh Ahli Materi Bahasa Inggris

\begin{tabular}{|c|c|}
\hline Saran & Perbaikan \\
\hline $\begin{array}{l}\text { Me m p e r b a i } \mathrm{i} \\
\text { penulisan bahasa } \\
\text { yang salah }\end{array}$ & $\begin{array}{l}\text { Revisi bahasa di goal (Tujuan) } \\
\text { Fenimena } \rightarrow \text { Fenomena } \\
\text { Dan } \rightarrow \text { And }\end{array}$ \\
\hline $\begin{array}{l}\text { Mem perjelas } \\
\text { i n t r u k i } \\
\text { penulisan dari } \\
\text { setiap materi }\end{array}$ & $\begin{array}{l}\text { Teks yang lebih dari satu } \\
\text { paragraph di tab } \\
\text { Di menu describing people kasih } \\
\text { arahan cara describing people } \\
\text { Perjelas instruksi menulis } \\
\text { describing places } \\
\text { Revisi di essential grammar }\end{array}$ \\
\hline $\begin{array}{l}\text { Ketidak sesuaian } \\
\text { antara teks dan } \\
\text { audio }\end{array}$ & $\begin{array}{l}\text { Di menu describing things ada satu } \\
\text { teks yang tidak sesuai dengan } \\
\text { audio dan harus diperbaiki }\end{array}$ \\
\hline \multirow{2}{*}{$\begin{array}{l}\text { Me m perbaiki } \\
\text { teks rangkuman } \\
\text { dan penggunaan } \\
\text { tombol }\end{array}$} & $\begin{array}{l}\text { Membuat sub konten baru untuk } \\
\text { rangkuman (Summary) }\end{array}$ \\
\hline & $\begin{array}{l}\text { Di final test beri tombol back and } \\
\text { forth }\end{array}$ \\
\hline
\end{tabular}

Sedangkan ahli media pembelajaran oleh Cecep Kustandi, M.Pd memberikan beberapa masukan berikut ini:

Tabel 6.

Saran Perbaikan dalam Proses Pengembangan oleh Ahli Media Pembelajaran

\begin{tabular}{ll}
\hline \multicolumn{1}{c}{ Saran } & \multicolumn{1}{c}{ Perbaikan } \\
\hline $\begin{array}{l}\text { Gunakan 9 element } \\
\text { of instruction }\end{array}$ & $\begin{array}{l}\text { Dari 9 elemen instruksi salah } \\
\text { satunya harus ada point } \\
\text { tentang mengkonfirmasi materi } \\
\text { sebelumnya }\end{array}$ \\
\hline $\begin{array}{l}\text { P e n a m b a h a n } \\
\text { deskripsi program }\end{array}$ & $\begin{array}{l}\text { Penambahan deskripsi program } \\
\text { untuk kesimpulan materi } \\
\text { (rangkuman) }\end{array}$ \\
\hline Kemas dengan baik & $\begin{array}{l}\text { Media harus menarik perhatian } \\
\text { peserta didik }\end{array}$ \\
\hline
\end{tabular}

Selanjutnya, pada tahap akhir dilakukan penilaian kualitas media oleh ketiga ahli tersebut. Hasil uji ahli secara keseluruhan terhadap media pembelajaran CAI dapat dilihat pada tabel 6 berikutini.
Tabel 7.

Rekapitulasi Hasil Evaluasi Kualitas Media CAI oleh 3 orang Ahli

\begin{tabular}{lll}
\hline \multicolumn{1}{c}{ Ahli } & Rata- Rata & Kategori \\
\hline Desain Pembelajaran & 3,6 & Sangat Baik \\
Materi & 3,3 & Sangat Baik \\
Media & 3,6 & Sangat Baik \\
\hline
\end{tabular}

Berdasarkan hasil evaluasi dari ketiga ahli dan beberapa saran yang diberikan untuk memperbaiki media pembelajaran CAI dalam penelitian ini, prototipe media CAI telah diperbaiki dan diujicobakan pada siswa calon pengguna media.

Pertama, dilakukan uji satu-satu. Uji coba satu-satu dilakukan kepada 3 orang siswa dengan latar belakang kemampuan akademik yang berbeda yaitu tinggi, sedang dan rendah. Uji coba satu-satu ini dilakukan untuk mengetahui kelayakan produk media CAI dilihat dari lima aspek yaitu aspek konten, aspek desain pembelajaran, aspek petunjuk dan penggunaan, aspek tempilan isi materi dan aspek gambar dan musik dengan jumlah indikator sebanyak 14 .

Tabel 8.

Rekapitulasi Hasil Uji Satu-Satu oleh Pengguna

\begin{tabular}{|c|c|c|c|c|}
\hline \multirow{2}{*}{ Aspek } & \multicolumn{3}{|c|}{ Partisipan } & \multirow{2}{*}{$\begin{array}{l}\text { Rata Rata } \\
\text { Penilaian }\end{array}$} \\
\hline & 1 & 2 & 3 & \\
\hline Konten & 3 & 3,5 & 3 & 3,1 \\
\hline $\begin{array}{l}\text { Desain } \\
\text { Pembelajaran }\end{array}$ & 3,5 & 3,5 & 3,5 & 3,5 \\
\hline $\begin{array}{l}\text { Petunjuk dan } \\
\text { Penggunaan }\end{array}$ & 3,6 & 3,3 & 3,3 & 3,4 \\
\hline $\begin{array}{l}\text { Tampilan isi } \\
\text { materi }\end{array}$ & 3,5 & 4 & 4 & 3,8 \\
\hline $\begin{array}{l}\text { Gambar dan } \\
\text { Musik }\end{array}$ & 3,3 & 3,3 & 3,6 & 3,4 \\
\hline $\begin{array}{l}\text { Rata-Rata } \\
\text { Keseluruhan }\end{array}$ & 3,38 & 3,52 & 3,48 & 3,46 \\
\hline Kriteria & $\begin{array}{c}\text { Sangat } \\
\text { Baik }\end{array}$ & $\begin{array}{l}\text { Sangat } \\
\text { Baik }\end{array}$ & $\begin{array}{c}\text { Sangat } \\
\text { Baik }\end{array}$ & $\begin{array}{c}\text { Sangat } \\
\text { Baik }\end{array}$ \\
\hline
\end{tabular}

Terdapat saran yang diberikan oleh responden setelah uji ini dilaksanakan, saran tersebut adalah penambahan soal latihan dengan tujuan untuk lebih mudah memahami materi dan meperjelas audio yang diperdengarkan dalam kegiatan belajar. Tindak lanjut untuk saran ini adalah menambah soal pada uji sumatif.

Selanjutnya dilakukan ujicoba media CAI yang telah dikembangkan pada 8 orang siswa untuk digunakan pada kelompok kecil. 
Tabel 9.

Rekapitulasi Hasil Evaluasi Kelompok Kecil oleh Pengguna

\begin{tabular}{lc}
\hline \multicolumn{1}{c}{ Aspek } & Rata-Rata \\
\hline Konten & 3,31 \\
Desain Pembelajaran & 3,46 \\
Petunjuk dan Penggunaan & 3,45 \\
Tampilan isi materi & 3,56 \\
Gambar dan Musik & 3,46 \\
\hline Rata-Rata Keseluruhan & 3,44 \\
\hline Kriteria & Sangat Baik \\
\hline
\end{tabular}

Saran perbaikan yang diberikan oleh pengguna pada uji satu-satu dan kelompok kecil diperbaiki dan setelahnya diimplementasikan pada kelas $\mathrm{X}$ mata pelajaran Bahasa Inggris.

Berdasarkan hasil ujicoba lapangan yang dilakukan terhadap 19 siswa diperoleh skor rata-rata keseluruhan 3,46. Hasil ini menyatakan bahwa media pembelajaran CAI dilihat dari aspek konten, aspek desain pembelajaran, petunjuk dan penggunaan, tampilan isi materi dan aspek gambar dan musik dinilai sangat baik dan layak digunakan dalam pembelajaran.

Berdasarkan hasil uji kelayakan secara teoritis dan empiris menunjukan bahwa media CAI berada pada kategori yang sangat baik. Sesuai dengan hasil analisis tersebut dapat disimpulkan bahwa media pembelajaran berbantuan komputer (CAI) yang dikembangkan memenuhi kriteria layak digunakan dalam pembelajaran.

Untuk mengetahui efektivitas media, sebelum diberikan media CAI ini, siswa diberikan pre-test untuk mengetahui tingkat ketercapaian materi pada siswa berdasarkan tujuan pembelajaran yang telah dirumuskan pada fase desain. Setelah menggunakan media CAI di laboratorium komputer, siswa diberikan post-test.

Berdasarkan data hasil belajar siswa presentase ketuntasan hasil belajar siswa setelah menggunakan media CAI sebesar 90\%, dimana siswa yang memenuhi KKM sebanyak 18 orang dari 19, dibandingkan hasil pretest dimana hanya hanya 3 orang saja yang memenuhi KKM $>75$. Apabila dilihat dari rata-ratanya dapat diketahui bahwa rata-rata nilai pretest adalah 56 , sedangkan rata-rata nilai posttest adalah 77,2 sehingga dapat disimpulkan bahwa media CAI terbukti efektif sebagai media belajar yang dapat meningkatkan hasil belajar siswa. Untuk mengetahui apakah terdapat perbedaan kenaikan yang signifikan antara pretest dan post-test, peneliti juga melakukan uji signifikansi perbedaan rata-rata pretest dan posttest dengan menggunakan uji-t.

\section{Rekapitulasi Ketuntasan Belajar}

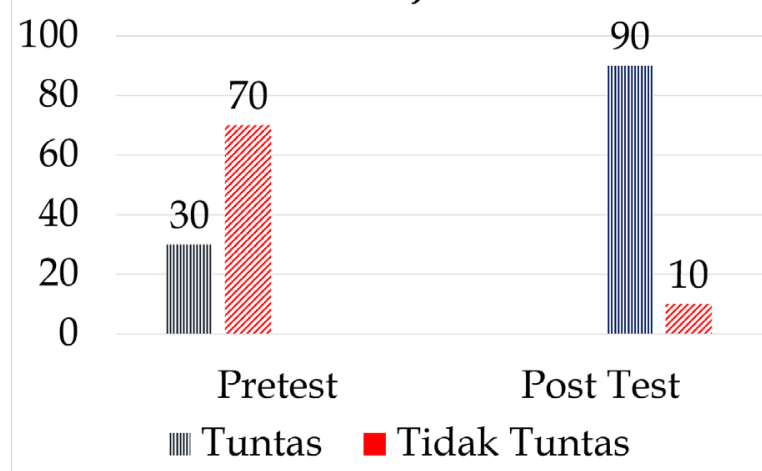

Gambar 5. Grafik Ketuntasan Belajar Siswa Sebelum dan Setelah Menggunakan CAI

Perubahan persentase hasil belajar siswa setelah menggunakan media CAI adalah 90\%. Terlihat 18 dari 19 orang siswa memenuhi KKM. Jika dibandingkan dengan hasil pretest, 15 orang siswa yang sebelumnya tidak mampu mencapai KKM, mampu mencapainya dalam posttest. Perbaikan juga dapat dilihat dari nilai rata-rata hasil belajar ke 19 siswa tersebut. Rata-rata nilai naik dari 56 saat pretest menjadi 77,2 saat posttest. Maka dapat disimpulkan bahwa media CAI terbukti efektif sebagai media belajar dan dapat meningkatkan hasil belajar siswa. Untuk mengetahui besar signifikasi perubahan tersebut, dapat dilihat dari hasil uji t statistik pretest dan posttest.

Dari hasil uji t statistik didapat nilai t hitung sebesar -7,538461 dengan $t$ tabel sebesar -2,101 dengan taraf signifikasi 0,025 . Nilai t hitung lebih kecil dari t-tabel begitupun dengan nilai signifikasi yang lebih kecil dari alpha $(0,05)$, maka dapat diambil kesimpulan bahwa ada perubahan yang signifikan antara hasil belajar siswa pretest dan posttest. Oleh karena itu, penerapan media CAI untuk pembelajaran Bahasa Inggris terbukti efektif untuk meningkatkan hasil belajar siswa.

\section{Pembahasan}

Penelitian ini telah menghasilkan sebuah produk media pembelajaran berbantuan komputer (CAI) dengan tujuan untuk membantu guru menyampaikan materi yang disampaikan kepada peserta didik. Berdasarkan hasil wawancara dengan tenaga pendidik disini peneliti menyimpulkan bahwa dibutuhkan media pembelajaran yang efektif dan 
dapat membantu peserta didik dalam memahami materi yang disampaikan.

Nama produk dari hasil penelitian ini adalah media pembelajaran CAI (Computer Assisted Instruction) pada mata pelajaran Bahasa Inggris. Dalam media ini terdapat tiga cakupan materi yang dipelajari yaitu materi tentang describing people, describing place and describing things. Sasaran dari pengguna modul ini adalah siswa kelas $X$.

Faktor pendukung dalam penggunaan media pembelajaran berbasis komputer (CAI) pada mata pelajaran Bahasa Inggris adalah adanya inisiatif dan kesadaran dari guru mata pelajaran Bahasa Inggris untuk menggunakan media CAI, sehingga terjadi suasana pembelajaran yang lebih kondusif, variatif dan optimal dari aspek tercapainya tujuan pembelajaran. Sedangkan faktor-faktor penghambat dalam penggunaan media CAI adalah biaya pengadaan dan perawatan media berbasis komputer tinggi.

Keunggulan penerapan media CAI dalam suatu pembelajaran adalah untuk memungkinkan penyampaian materi lebih menarik.Mempermudah dan mengefisienkan waktu pembelajaran karena siswa dapat lebih memahami materi dengan bantuan media. Sedangkan kelemahan penerapan media CAI dalam suatu pembelajaran adalah waktu untuk menyiapkan, pembuatan, dan pengembangan media cukup banyak.SDM harus memahami pengoperasian teknologi komputer.

\section{PENUTUP}

Hasil analisis yang dilaksanakan di SMK Daarussalaam Kabupaten Sukabumi menunjukkan terbatasnya media pembelajaran yang guru gunakan, sehingga siswa merasa bosan saat proses pembelajaran Bahasa Inggris.

Hasil validasi menurut para ahli menunjukkan penilaian aspek-aspek yang dikategorikan sangat baik dan bagus, sehingga pengembangan media $C A I$ yang dilakukan di SMK Daarussalaam terhadap mata pelajaran Bahasa Inggris dinilai layak digunakan dalam kegiatan proses pembelajaran tersebut.

Hasil analisis uji t statistik terhadap hasil belajar siswa menunjukan adanya perbedaan yang signifikan dari hasil pretest dan posttest siswa. Perbedaan yang signifikan ini dibuktikan dari hasil thitung yang lebih kecil dari $\mathrm{t}$ tabel dan hasil nilai signifikasi yang lebih kecil dari alpha. Oleh karena itu, dapat disimpulkan bahwa penerapan media CAI terhadap pembelajaran mata pelajaran Bahasa Inggris terbukti efektif dalam meningkatkan hasil belajar siswa.

\section{DAFTAR PUSTAKA}

Ariasa, K., Santyadiputra, G. S., \& Sindu, I. G. P. (2016). Pengembangan E-Modul Berbantuan Media CAI Pada Mata Pelajaran Fotografi Kelas X Desain Komunikasi Visual di SMK Negeri 1 Sukasada. Jurnal Nasional Pendidikan Teknik Informatika: JANAPATI, 5(3), 127-135, DOI: http://dx.doi.org/10.23887/janapati.v5i3.9919.

Arikunto, S. (2012) Prosedur Suatu Penelitian: Pendekatan Praktek. Jakarta: Rineka Cipta.

Cahyaningrum, A., \& Sumarno, A. (2020). Pengembangan Media CAI (Computer Assisted Instruction) Materi Sistem Pencernaan Manusia pada Mata Pelajaran Biologi Kelas VIII MTS Maskumambang Gresik. Jurnal Mahasiswa Teknologi Pendidikan, 10(29), 1-13, diakses melalui https://jurnalmahasiswa.unesa.ac.id/ index.php/jmtp/article/view/31572

Fadhilah, S. J., \& Mariono, A. (2020). Pengembangan Media Pembelajaran CAI untuk Meningkatkan Hasil Belajar pada Mata Pelajaran Kimia Materi Pokok Struktur Atom Kelas X di SMA Cendekia Sidoarjo. Jurnal Mahasiswa Teknologi Pendidikan, 10(29), 1-12, diakses melalui https:/ / jurnalmahasiswa.unesa.ac.id/index.php/jmtp/ article/view/31572

Hamalik, O. (1986). Media Pendidikan. Bandung: Alumni.

Hannafin, M. J., Peck, L. L. (1998). The Design Development and Education of Instructional Software. New York: Mc. Millan Publ., Co

Pribadi, B. A. (2017). Media dan Teknologi dalam Pembelajaran. Jakarta: Kencana.

Purwani, F. (2013). Perancangan Perangkat Lunak Media Pembelajaran Menggunakan Computer Assisted Instruction (CAI) untuk Pembelajaran Ilmu Tajwid Berbasis Web, Intizar, 19 (2), 287300, diakses melalui http://jurnal.radenfatah. ac.id/index.php/intizar/article/view/414

Roblyer, M. D. (2009). Integrating Educational Technology into Teaching. Pearson: Canada.

Rohani, Ahmad. (1997). Media Instruksional Edukatif. Jakarta: Rineka Cipta.

Samsudin, S. (2017). Aplikasi computer aided instruction (CAI) dalam pembelajaran matematika bangun ruang. Jurnal Teknik Informatika, 10(2), 169-182, DOI: http:/ /dx.doi. org/10.15408/jti.v10i2.6995

Sugiyono. (2014). Metode Penelitian Kuantitatif, Kualitatif dan RED. Bandung: Alfabeta. 
Pengembangan Media CAI...

Yulianti, H. \& Kristanto, A. (2018). Pengembangan Media Computer Assisted Instruction Mata Pelajaran Dasar Desain Grafis untuk Kelas X Jurusan Multimedia di SMK Muhammadiyah
2 Surabaya. Jurnal Mahasiswa Teknologi Pendidikan, 9(2), 1-9, diakses melalui https:// jurnalmahasiswa.unesa.ac.id/index.php/jmtp/ article/view/31572 